\title{
Yield variation in organic winter wheat: a diagnostic study in the Southeast of France
}

\author{
Christophe DAVID ${ }^{a *}$, Marie-Hélène JEUFFROY ${ }^{\mathrm{b}}$, John HENNING ${ }^{\mathrm{c}}$, Jean-Marc MEYNARD ${ }^{\mathrm{d}}$ \\ a ISARA Lyon, 69288 Lyon Cedex 02, France \\ b UMR d'Agronomie INRA-INA PG, BP 01, 78850 Thiverval Grignon, France \\ ${ }^{c}$ McGill University, Department of Agricultural Economics, 211 Lakeshore, Sainte-Anne de Bellevue, QC, Canada H9X 3V9 \\ d INRA SAD, BP 01, 78850 Thiverval Grignon, France
}

(Accepted 18 January 2005)

\begin{abstract}
A diagnostic method for assessing regional variations in yield was implemented for a network of 24 organic wheat fields located in two neighboring regions, Diois and Val de Drôme (France). We studied: yield and its components; field environmental conditions of the fields; relations between indicators of potential limiting factors and yield components; and linkages between crop management and yield-limiting factors. The yield performances were low and variable $\left(3.5 \pm 1.4 \mathrm{t} \cdot \mathrm{ha}^{-1}\right)$. The relative kernel number $(\mathrm{RKN})$ was significantly related to nitrogen nutrition and weed density at flowering. The nitrogen nutrition index (NNIf) had a strong and positive effect on relative kernel number, while weed density $(1 / \mathrm{WF})$ had a negative effect. The percentage of kernel number variation explained by the regression model $(\mathrm{RKN}=0.112+0.609 \times$ NNIf $+0.2 \times 1 / \mathrm{WF}$ ) was adequate (Adj. $\mathrm{R}^{2}=0.53$ ) with a RMSE of 0.09 . The duration of the period of grain filling, reflected in the temperature sum, had a strong and positive effect on relative kernel weight (RTKW), while soil compaction and high temperature had a negative influence. Adjusted $\mathrm{R}^{2}$ for the model was 0.42 with a RMSE of 0.16 . The results confirm that legumes preceding crops improve nitrogen nutrition on subsequent winter wheat, e.g. the Nitrogen Nutrition Index at flowering (NNIf) $=0.51 \pm 0.12$ for a crop rotation with a rate of legumes over $37 \%$ vs. $0.41 \pm 0.11$ for a crop rotation with a rate of legumes under $25 \%$. Alfalfa preceding crops significantly limited the weed density at harvest while stony soils and early sowing (before November 1st) enhanced weed density.
\end{abstract}

organic farming / winter wheat / yield / limiting factors / diagnostic method

\section{INTRODUCTION}

Wheat occupies more than half the area devoted to organic cereals in Europe (European Commission, 2001) and is subject to strong demand from millers and animal feed processors. Organic wheat yields are lower (20 to $40 \%$ lower) than conventional (Keatinge et al., 2000; Offerman and Nieberg, 2000), and mainly attributable to production constraints: nitrogen supply (Von Fragstein, 1996; Berry et al., 2002; Deria et al., 2003), weeds (Bond and Grundy, 2001; Barberi, 2002), and pests and diseases (Lammerts van Bueren et al., 2002). Moreover, soil fertility (Stewart and Dwyer, 1987) can be impaired by soil compaction (Meynard et al., 1981; Sheperd et al., 2002) and water deficit (Dunbabin et al., 2002). Thus, organic crop production is characterized by multiple limiting factors and limited resources availability (Halberg and Kristensen, 1997; Kho, 2000), that reduce resource-use efficiency, yield and yield stability (Edwards-Jones and Howells, 2001; Tamm, 2000; Mäder et al., 2002).
Although the development of decision-making tools for the management of cropping systems requires knowledge of the effects of the main limiting factors (Loyce et al., 2002; Meynard et al., 2002; David et al., 2004), little diagnostic work on specific crops has been done in organic agriculture. Even though previous research on organic cereals has analyzed individual limiting factors (Taylor et al., 2001), less attention has been given to the interactions between all factors, and how these relate to crop management. Doré et al. (1997) formalized a diagnostic method for assessing regional variations in crop yield, that provides an integrated evaluation of cropping systems. This method has been frequently applied to conventional cereals, resulting in improvements in farm practices (Sebillotte, 1980; Boiffin et al., 1981; Meynard, 1985; Aubry et al., 1994; Leterne et al., 1994; Le Bail and Meynard, 2003). It is used to identify and rank crop management, weather and edaphic factors that are responsible for differences in yield. The diagnostic involves an analysis of crop yield using a description of the relationships between crop management, environment and yield

\footnotetext{
* Corresponding author: davidc@isara.fr
} 
Table I. Main characteristics of the 24 fields studied in the network.

\begin{tabular}{|c|c|c|c|c|c|c|c|c|c|c|c|c|c|c|c|}
\hline Code $^{0}$ & Location & Year & Soil $^{1}$ & $\begin{array}{c}\mathrm{SOM}^{2} \\
\text { g per } 100 \mathrm{~g}\end{array}$ & $\begin{array}{c}\text { Cumulative } \\
\text { rainfall }^{3} \\
\mathrm{~mm}\end{array}$ & $\begin{array}{c}\text { Mean } \\
\text { temperature } \\
{ }^{\circ} \mathrm{C}\end{array}$ & $\begin{array}{c}\text { Potential } \\
\text { ETP } \\
\mathrm{mm} \cdot \mathrm{d}^{-1}\end{array}$ & $\begin{array}{c}\text { Crop } \\
\text { rotation } \\
\% \text { leg }^{5}\end{array}$ & $\begin{array}{l}\text { Preceding } \\
\text { crop }\end{array}$ & Cultivar & $\begin{array}{c}\text { Sowing } \\
\text { date }\end{array}$ & $\begin{array}{c}\mathrm{N} \text { tot }^{6} \\
\mathrm{~kg} \mathrm{~N} \cdot \mathrm{ha}^{-1}\end{array}$ & $\begin{array}{c}\mathrm{N} \mathrm{org}^{7} \\
\mathrm{~kg} \mathrm{~N} \cdot \mathrm{ha}^{-1}\end{array}$ & $\mathrm{NAp}^{8}$ & $\begin{array}{c}\text { Number of } \\
\text { mechanical } \\
\text { weedings }\end{array}$ \\
\hline$\overline{\text { SD1 }}$ & Diois & $94-95$ & $\mathrm{C}$ & 3.7 & 866 & 9.8 & 2.5 & 25 & Sunflower & Sidéral & $19 / 10$ & 123 & 31 & 1 & 2 \\
\hline SV1 & Val Drôme & $94-95$ & $\mathrm{LC}$ & 2.3 & 360 & 11.4 & 2.4 & 25 & Sunflower & Sidéral & $25 / 11$ & 200 & 50 & 1 & 0 \\
\hline SV2 & Val Drôme & $94-95$ & $\mathrm{LC}$ & 2.1 & 500 & 11.5 & 2.4 & 25 & Sunflower & Sidéral & $21 / 10$ & 196 & 50 & 1 & 2 \\
\hline SD2 & Diois & $93-94$ & $\mathrm{LC}$ & 2.4 & 591 & 9.7 & 2.7 & 25 & Sunflower & Sidéral & $14 / 11$ & 138 & 42 & 1 & 1 \\
\hline OD1 & Diois & $93-94$ & $\mathrm{LC}$ & 2.2 & 619 & 9.5 & 2.6 & 12.5 & Wheat & Soissons & $20 / 10$ & 234 & 53 & 1 & 0 \\
\hline OD2 & Diois & $94-95$ & $\mathrm{LC}$ & 3.1 & 923 & 10.2 & 2.4 & 12.5 & Wheat & Soissons & $20 / 09$ & 135 & 30 & 2 & 0 \\
\hline FV1 & Val Drôme & $95-96$ & LSC & 3.0 & 242 & 14 & 3.4 & 25 & Maize & Florence Aurore & $15 / 02$ & 241 & 101 & 2 & 0 \\
\hline FD1 & Diois & $94-95$ & $\mathrm{CS}$ & 2.7 & 785 & 9.7 & 2.6 & 25 & Sunflower & Florence Aurore & $30 / 10$ & 108 & 28 & 1 & 1 \\
\hline FV2 & Val Drôme & $93-94$ & CS & 2.6 & 518 & 11 & 2.3 & 25 & Set aside & Florence Aurore & $18 / 11$ & 137 & 45 & 2 & 1 \\
\hline FV3 & Val Drôme & $95-96$ & $\mathrm{CS}$ & 2.6 & 745 & 9.4 & 2.7 & 25 & Rye & Florence Aurore & $28 / 11$ & 245 & 77 & 1 & 2 \\
\hline RD1 & Diois & $94-95$ & $\mathrm{CS}$ & 2.4 & 877 & 9.8 & 2.4 & 25 & Sunflower & Renan & $28 / 9$ & 191 & 112 & 1 & 2 \\
\hline OV1 & Val Drôme & $93-94$ & LSC & 2.4 & 518 & 11 & 2.3 & 25 & Soya & Soissons & $14 / 11$ & 213 & 50 & 2 & 1 \\
\hline SD3 & Diois & $95-96$ & $\mathrm{CS}$ & 2.8 & 826 & 9.8 & 2.6 & 37.5 & Lucerne & Sidéral & $13 / 10$ & 160 & 0 & 0 & 0 \\
\hline SD4 & Diois & $94-95$ & $\mathrm{LC}$ & 2.5 & 811 & 9.7 & 2.5 & 50 & Wheat & Sidéral & $23 / 10$ & 169 & 26 & 1 & 0 \\
\hline $\mathrm{RD} 2$ & Diois & $95-96$ & $\mathrm{LC}$ & 4.0 & 810 & 9.8 & 2.6 & 37.5 & Sunflower & Renan & $15 / 10$ & 159 & 25 & 2 & 1 \\
\hline SD5 & Diois & $93-94$ & $\mathrm{LC}$ & 2.5 & 595 & 9.6 & 2.7 & 50 & Lucerne & Sidéral & $10 / 11$ & 115 & 0 & 0 & 0 \\
\hline SD6 & Diois & $93-94$ & $\mathrm{LC}$ & 2.4 & 591 & 9.7 & 2.7 & 50 & Lucerne & Sidéral & $14 / 11$ & 198 & 64 & 1 & 1 \\
\hline OD3 & Diois & $93-94$ & $\mathrm{C}$ & 3.6 & 637 & 9.6 & 2.6 & 37.5 & Lucerne & Soissons & $13 / 10$ & 158 & 25 & 2 & 0 \\
\hline OD4 & Diois & $94-95$ & LSC & 2.8 & 866 & 9.8 & 2.5 & 37.5 & Lucerne & Soissons & $15 / 10$ & 145 & 0 & 0 & 0 \\
\hline OD5 & Diois & $95-96$ & $\mathrm{CS}$ & 2.4 & 835 & 9.6 & 2.5 & 50 & Lucerne & Soissons & $11 / 10$ & 210 & 56 & 1 & 0 \\
\hline FV4 & Val Drôme & $94-95$ & LSC & 3.0 & 360 & 11.4 & 2.3 & 37.5 & Chick pea & Florence Aurore & $21 / 11$ & 263 & 88 & 1 & 1 \\
\hline FV5 & Val Drôme & $93-94$ & $\mathrm{LC}$ & 2.5 & 518 & 11 & 2.3 & 37.5 & Clover & Florence Aurore & $18 / 11$ & 144 & 45 & 2 & 1 \\
\hline FV6 & Val Drôme & $94-95$ & $\mathrm{LC}$ & 2.6 & 363 & 11.4 & 2.3 & 37.5 & Soya & Florence Aurore & $17 / 10$ & 213 & 58 & 1 & 1 \\
\hline RV1 & Val Drôme & $95-96$ & $\mathrm{CS}$ & 2.4 & 832 & 9.5 & 2.5 & 50 & Lucerne & Renan & $15 / 10$ & 259 & 60 & 2 & 1 \\
\hline
\end{tabular}

${ }^{0}$ Code SD1: S = cultivar - D = location 1 = field number; ${ }^{1}$ L: Loam, S: Sand, C: Clay; ${ }^{2}$ SOM Soil organic matter; ${ }^{3}$ Cumulative rainfall between sowing and harvest; ${ }^{4}$ Mean temperature = average of daily air temperature between sowing and harvest; ${ }^{5}$ Percentage of legumes in the rotation; ${ }^{6} \mathrm{~N}$ tot: The $\mathrm{N}$ contributions of previous crop residues, humus, organic amendments and organic fertilizer (in $\mathrm{kg}^{-1}$ ); ${ }^{7} \mathrm{~N}$ org: Total organic $\mathrm{N}$ application in spring (in $\mathrm{kg} \mathrm{ha}^{-1}$ ) estimated according to Machet et al. (1991); ${ }^{8} \mathrm{~N}$ Ap: Time of application; 1: before Feekes scale 6; - 2: after Feekes scale 6; 0: no application.

for each field, as described by Boiffin et al. (1981) and Meynard and David (1992). For instance, Leterme et al. (1994) analyzed the effect of crop management and environment on wheat yield variation in Thymerais, France $\left(48.3^{\circ} \mathrm{N}, 1.3^{\circ} \mathrm{E}\right)$. It was established that the major factors responsible for yield differences were drought stress during stem elongation and meiosis, root and stem diseases and soil structure. Then these factors were explained by differences in soil moisture capacity, rainfall distribution, sowing date and the nature of the preceding crops.

This paper focuses on understanding organic wheat yield performance in terms of yield-limiting factors and crop management characteristics. The analysis consisted of four stages: (i) yield and its components were described, (ii) we characterized the environmental conditions of the fields, (iii) we analyzed the relations between indicators of possible limiting factors and yield components, and (iv) determined the relations between crop management and yield-limiting factors.

\section{MATERIALS AND METHODS}

\subsection{On-farm network}

\subsubsection{The field network}

The study area is located in the Southeast of France, in the region of Drôme, where organic production is concentrated (Observatoire nationale de l'agriculture biologique, 2003). The region $\left(25 \mathrm{~km}\right.$ North to South, $70 \mathrm{~km}$ East to West; $44.5^{\circ} \mathrm{N}$, $4-5^{\circ} \mathrm{E}$ ) is composed of two small areas; the Diois, a hilly area where farming systems are diverse (livestock, crop production and perennial systems), and the Val de Drôme, a large plain specialized in arable crops.

Twenty-four organic winter wheat fields were selected from 11 organic mixed or arable farms to create a wide range of conditions in terms of cropping systems and environmental conditions (Tab. I) and were followed from 1993 to 1996. Together, 
Table II. Reference values for kernel number threshold and maximum thousand kernel weight from Gate (1995) and earliness and disease resistance scores on a scale from 0 to 9 (Brancourt-Hulmel et al., 1999).

\begin{tabular}{lccccccc}
\hline Cultivar & $\begin{array}{c}\text { Kernel Number } \\
\text { threshold (KNref) } \\
\text { in grains } \cdot \mathrm{m}^{-2}\end{array}$ & $\begin{array}{c}\text { Maximum Thousand } \\
\text { Kernel Weight (TKWref) } \\
\text { if KN }<\text { KNref } \\
\text { in g at } 15 \% \text { moisture }\end{array}$ & $\begin{array}{c}\text { Maximum Thousand Kernel } \\
\text { Weight (TKWref) } \\
\text { if KN }>\text { KNref } \\
\text { in g at } 15 \% \text { moisture }\end{array}$ & $\begin{array}{c}\text { Earliness } \\
\text { at heading }\end{array}$ & $\begin{array}{c}\text { Brown rust } \\
\text { Powdery } \\
\text { mildew }\end{array}$ & $\begin{array}{c}\text { Septoria } \\
\text { nodorum }\end{array}$ \\
\hline Sideral & 26500 & 45 & TKWref $=-0.0023 \mathrm{KN}+108$ & 7.5 & 5 & 4 \\
Renan & 17000 & 54 & TKWref $=-0.0032 \mathrm{KN}+108$ & 6 & 8 & 6 \\
Soissons & 29000 & 46 & TKWref $=-0.0015 \mathrm{KN}+91$ & 7 & 2 & 6 \\
Florence Aurore & 15000 & 57 & TKWref $=-0.0035 \mathrm{KN}+110$ & 5 & 5 & NA & 2 \\
\hline
\end{tabular}

${ }^{1}$ Earliness of heading from 1 (very late) to 9 (vary early).

the fields are referred to as the "field network", a term often used in French agronomic on-farm research (Leterne et al., 1994). The selection of farmers' fields for the sample was based on farm and field typologies (David and Fabre). The farming systems were defined by three criteria: (i) the main characteristic of the farming system, i.e. mixed vs. arable, (ii) the significance ( $\%$ area and $\%$ profits) of the organic cereal sector, from 5 to $80 \%$ and (iii) the time period since conversion, from 1 to 20 years. The field types were defined by (i) soil type, (ii) crop rotation and (iii) preceding crop (see Sect. 2.1.2).

The fields were on the 4 major regional soil types defined by top-soil texture (FAO, 1998): clayey calcareous soil (C), medium loamy calcareous soil (LC), clay and sandy soil (CS) and loamy clay and sandy soil (LSC). The proportion of stones in volume ranged from $25 \%$ to $60 \%$ in the top-soil layer for soils C and LC, while it was under $10 \%$ for soils CS and LSC. Soil organic matter content (SOM) of the arable layer ranged from 2.1 to $4.0 \mathrm{~g}$ per $1000 \mathrm{~g}$ (Tab. I).

\subsubsection{Crop management}

The crop management was characterized by crop rotation (CR), previous crop (PC), sowing date (SD), cultivar (C), soil types (S), location (LOC), $\mathrm{N}$ supply ( $\mathrm{N}$ tot and $\mathrm{N}$ org) and date of $\mathrm{N}$ application (Nap) (Tab. I). The factor CR differentiated the two crop rotations: (i) less than $25 \%$ legumes (clover, soyabean and chickpea) and more than $50 \%$ cereals, (ii) more than $37 \%$ legumes (alfalfa and/or grain legumes). The factor PC took into account the presence or absence of legumes. Except for sunflowers, summer cash crops (maize, chickpea and soyabean) were irrigated. The crop residues were buried except on fields FV3. Sowing date ranged from the end of September to mid-February depending on the soil, weather conditions and preceding crop. The factor SD partitions the data into two classes, before and after the 1st of November.

Four wheat cultivars (Sidéral, Soissons, Florence Aurore and Renan) were studied, all of which are common in organic agriculture. Table II presents the characteristics of the cultivars, in terms of earliness and susceptibility to various diseases.

Total $\mathrm{N}$ supply ( $\mathrm{N}$ tot) during the crop cycle varied from 108 to $263 \mathrm{~kg} \mathrm{~N} \cdot \mathrm{ha}^{-1}$ (Tab. I). This includes residual soil mineral $\mathrm{N}$ at the end of the winter, mineralized $\mathrm{N}$ from the soil organic matter and organic $\mathrm{N}$ fertilizer when applied. The soil $\mathrm{N}$ supply ranged from 79 to $199 \mathrm{~kg} \mathrm{~N} \cdot \mathrm{ha}^{-1}$, as estimated using the balance-sheet method (Machet et al., 1991). In the spring, organic fertilizers ( $\mathrm{N}$ org included chicken manure, feather meal or guano) ranged from 0 to $112 \mathrm{~kg} \mathrm{~N} \cdot \mathrm{ha}^{-1}$ (Tab. I).

\subsection{Measurements and analytical procedures}

\subsubsection{Soil and weather conditions}

In each field, the sampling site was defined as a homogeneous zone of $100 \mathrm{~m}^{2}$. Soil samples (10 per plot) were taken with a mechanical probe to a depth of $30 \mathrm{~cm}$ and analyzed for organic carbon (method: oxidation in $8 \%$ of $\mathrm{K}_{2} \mathrm{Cr}_{2} \mathrm{O}_{7}$ with $\mathrm{H}_{2} \mathrm{SO}_{4}$ solution), total $\mathrm{N}$ (Kjeldahl method), $\mathrm{pH}$ (water) and total $\mathrm{CaCO}_{3}$. Residual soil mineral $\mathrm{N}$ at the end of winter was determined from 15 samples taken from 3 depths, $30 \mathrm{~cm}$ apart to a depth of $90 \mathrm{~cm}$. Daily weather data (minimum and maximum air temperature, rainfall, radiation and evapotranspiration) were recorded at different stations of the French national weather network (Meteo France), located less than $25 \mathrm{~km}$ from each field.

\subsubsection{Determination of yield components}

At maturity, grain yield (GY) was determined from 4 samples per field $\left(0.25 \mathrm{~m}^{2}\right.$ each) and thousand-kernel weight (TKW) was established using 200 kernels per sample, both expressed at $15 \%$ moisture content. Kernel number (KN) was calculated as the ratio between grain yield and dry thousandkernel weight determined at maturity.

\subsubsection{Determination of relative kernel number $(R K N)$ and relative thousand-kernel weight (RTKW)}

Relative kernel number (RKN) and relative thousand-kernel weight (RTKW) are defined with respect to varietal reference values expected under optimum conditions (Tab. II). The relation between $\mathrm{KN}$ and maximum TKW is determined by competition effects (Fleury and Limaux, 1987). Below a variety-specific $\mathrm{KN}$ threshold, there is no competition for assimilates and TKW attains its maximum value; above the threshold, TKW decreases linearly with increasing $\mathrm{KN}$. The ratio of RKN and RTKW is expressed from 0 (heavy damage) to 1 (no damage).

\subsubsection{Indicators for yield-limiting factors}

Yield components described two distinct periods: $\mathrm{KN}$ expressed the vegetative period from sowing to flowering and 
TKW expressed the grain-filling period after flowering (Sebillotte, 1980; Brancourt-Humel et al., 1999). Indicators for factors limiting kernel number are indicated by $\mathrm{F}$ (for Flowering) and those limiting thousand-kernel weight by $\mathrm{H}$ (for Harvest). Each indicator is expressed on a scale from 0 for maximum stress to 1 in the absence of stress.

\subsubsection{Water stress}

Water stress was calculated as the ratio between the actual evapotranspiration and the potential crop evapotranspiration, computed on a daily basis by Brisson et al. (1992). Actual evapotranspiration depends on the soil water availability, the result of the inputs of rainfall and irrigation and outputs of evapotranspiration, and drainage. The calculations depend on soil water content (volumetric fraction) for the lower limit of plant availability (wilting point) and for the upper limit (field capacity). This calculation assumes that profile soil water storage is considered empty on the first of August. Any amount in excess of soil water storage capacity is lost as drainage (deep percolation or runoff). Potential crop evapotranspiration gives the evaporation rate which could occur at field capacity depending, on one hand, on the reference weather potential evapotranspiration (Penman formula), and, on the other hand, on the cultural coefficient, depending on the crop structure and the minimum leaf stomatal resistance. The water stress was assessed for both the vegetative phase, by the mean daily index between sowing and flowering $(\mathrm{HF})$, and for the grain-filling phase, from flowering to harvest $(\mathrm{HH})$.

\subsubsection{Solar radiation and temperature}

Fischer (1985) demonstrated significant effects of solar radiation and temperature on kernel number, particularly in the 30 days prior to anthesis. Hence, for this period, the photothermal quotient $(\mathrm{QF})$, defined as the mean daily solar radiation divided by the mean temperature, was calculated for each field.

High temperature stress has been shown to affect kernel weight, through a reduced duration of grain filling (Warrington et al., 1977). Gate (1995) showed that days with a mean temperature over $25^{\circ} \mathrm{C}$ during grain filling resulted in lower relative thousand-kernel weight. The index Hd keeps track of the number of these days. This index ranges from 1 , indicating no day with a mean temperature over $25^{\circ} \mathrm{C}$, to 0 for a situation with 9 days, corresponding to the maximum value accross fields. Furthermore, the thousand-kernel weight can be limited by the duration of the grain-filling period (Girard, 1997). The index (STH) expresses the ratio between observed cumulative temperature (calculated with $0{ }^{\circ} \mathrm{C}$ as a basis) from flowering to harvest and a maximum of 1404 degree-days.

\subsubsection{Weeds}

Weed density (plants per $\mathrm{m}^{2}$ ) was assessed at flowering (WF) (Feekes 10.5.3) (Stewart and Dwyer, 1987), and at the soft-dough stage (WH) (Feekes 11.2), from 3 quadrats of $0.25 \mathrm{~m}^{2}$ per replicate (Moreby et al., 1994). The number of plants of each weed species was counted to determine the total density. Taking the inverse of these density measures yields an index (1/WF and $1 / \mathrm{WH})$, ranging from 0 , for high weed density, to 1 in the absence of weeds. This index reflects the expectation that the competitiveness of individual weeds decreases as weed density increases (Cousens, 1985).

\subsubsection{Disease assessment}

The incidence of leaf diseases (brown rust, mildew and Septoria nodorum) was assessed on the upper two leaves at the softdough stage (Feekes 11.2), on 15 plants per field. The proportion of leaf area affected by foliar disease was used to express severity, through an index (D) ranging from 1, without disease, to 0 with $100 \%$ of the two leaves affected.

\subsubsection{Soil compaction}

In each field, a soil profile, $3 \mathrm{~m}$ wide (perpendicular to the direction of ploughing) and $1.2 \mathrm{~m}$ deep, was examined at the flowering stage (Feekes 10.5.3). The degree of compaction and clod size distribution, and also the internal structural porosity of clods, were used to assess soil compaction, as described by Roger-Estrade et al. (2004). An index (SC), suggested by David and Gautronneau (2002), characterized soil structure in 4 classes, from 1 , favorable structure to 0 , indicating compacted topsoil.

\subsubsection{Nitrogen nutrition}

At the flowering stage, aboveground biomass and its total $\mathrm{N}$ content were determined on two microplots $(0.5 \mathrm{~m} \times 2$ rows each) per replicate ( 3 per field). The samples were oven-dried $\left(48 \mathrm{~h}\right.$ at $\left.80^{\circ} \mathrm{C}\right)$, weighed and ground. $\mathrm{N}$ concentration of the samples was determined by the Dumas method, involving combustion of the ground plant material at about $1800{ }^{\circ} \mathrm{C}$, reduction of $\mathrm{N}$ oxides by reduced $\mathrm{Cu}$ at $600{ }^{\circ} \mathrm{C}$ and analysis of $\mathrm{N}_{2}$ by catharometry (Carlo-Erba NA 1500 Analyzer). Crop N status was expressed through a nitrogen nutrition index at flowering (NNIf) (Lemaire and Gastal, 1997), calculated using the critical N curve of Justes et al. (1994) as a reference. The nitrogen nutrition index expressed $\mathrm{N}$ deficiency when NNIf was below 0.9 (Justes et al., 1994; Meynard et al., 2002).

\subsection{Statistical analysis}

The statistical analyses of the data were performed with the STATA Statistical software (Hamilton, 2002). The relations between yields and their components were determined by simple linear regressions. The stepwise regression procedure was used to explain the reductions in yield components (RKN and RTKW) as linear combinations of the indicators of limiting factors. The parsimonious models retained only statistically significant terms, for which the probability values associated with a null hypothesis of a zero coefficient could be rejected at least at a $10 \%$ level of significance (Landau et al., 2000). The proportion of yield variation explained by the regression model was expressed in the adjusted coefficient of determination (Adj $\mathrm{R}^{2}$ ). We also evaluated the predictions of the regression model by comparing observed and simulated values, using the root mean square error of prediction (RMSE) (Wallach and Goffinet, 1989). The yield-limiting factors that were identified as responsible for differences in grain yield were explained on the basis of crop management characteristics and edaphic conditions. 
Table III. Results on grain yield (Y), kernel number (KN), thousand kernel yield (TKW) and indicators on weed density (1/WF and 1/WH) and water deficit ( $\mathrm{HF}$ and $\mathrm{HH}$ ) at flowering and harvest, photothermal quotient (QF), soil compaction (SC) and nitrogen nutrition index (NNIf) at flowering stage, ,foliar disease (D) at soft dough stage, temperature sum from flowering to harvest (STH) and number of days with mean temperature over $25^{\circ} \mathrm{C}$ during grain filling $(\mathrm{Hd})$.

\begin{tabular}{|c|c|c|c|c|c|c|c|c|c|c|c|c|c|c|c|c|}
\hline \multirow[t]{2}{*}{ Field } & \multicolumn{3}{|c|}{ Output variables ${ }^{1}$} & \multicolumn{3}{|c|}{ Reduction variables $^{2}$} & \multicolumn{5}{|c|}{$\begin{array}{l}\text { Indicators on limiting-factors } \\
\text { at flowering stage }\end{array}$} & \multicolumn{5}{|c|}{$\begin{array}{c}\text { Indicators on limiting factors at soft-dough } \\
\text { stage or harvest }\end{array}$} \\
\hline & $\mathrm{Y}$ & $\mathrm{KN}$ & TKW & RY & RKN & RTKW & $1 / \mathrm{WF}^{3}$ & $\mathrm{HF}$ & $\mathrm{QF}$ & NNIf & $\mathrm{SC}$ & $1 / \mathrm{WH}$ & $\mathrm{D}$ & $\mathrm{HH}$ & STH & $\mathrm{Hd}$ \\
\hline SD1 & 3.9 & 9856 & 40.0 & 0.33 & 0.37 & 0.89 & 0.01 & 1.00 & 1.00 & 0.46 & 1.00 & 0.01 & 0.50 & 0.56 & 0.95 & 0.78 \\
\hline SV1 & 4.1 & 9350 & 44.0 & 0.34 & 0.35 & 0.98 & 0.03 & 0.98 & 0.80 & 0.26 & 0.25 & 0.02 & 0.40 & 0.45 & 1.00 & 0.33 \\
\hline SV2 & 4.2 & 9050 & 46.0 & 0.35 & 0.34 & 1.02 & 0.02 & 0.98 & 0.75 & 0.22 & 0.25 & 0.01 & 0.30 & 0.41 & 0.93 & 0.33 \\
\hline SD2 & 3.6 & 12450 & 28.8 & 0.30 & 0.47 & 0.64 & 0.01 & 0.99 & 0.88 & 0.57 & 0.25 & 0.05 & 0.93 & 0.43 & 0.82 & 0.78 \\
\hline OD1 & 3.6 & 12070 & 30.0 & 0.27 & 0.42 & 0.66 & 0.08 & 0.98 & 0.89 & 0.45 & 0.50 & 0.02 & 0.91 & 0.45 & 0.83 & 0.89 \\
\hline OD2 & 2.6 & 6375 & 41.0 & 0.20 & 0.22 & 0.90 & 0.17 & 0.99 & 1.00 & 0.30 & 0.50 & 0.02 & 0.78 & 0.62 & 0.77 & 1.00 \\
\hline FV1 & 3.6 & 8562 & 41.9 & 0.42 & 0.57 & 0.74 & 1.00 & 1.00 & 0.79 & 0.47 & 0.50 & 0.02 & 1.00 & 0.37 & 0.81 & 0.33 \\
\hline FD1 & 1.5 & 3770 & 41.0 & 0.18 & 0.25 & 0.72 & 0.01 & 0.99 & 0.98 & 0.27 & 0.50 & 0.04 & 0.85 & 0.26 & 0.76 & 1.00 \\
\hline FV2 & 1.6 & 3648 & 43.1 & 0.19 & 0.24 & 0.76 & 0.02 & 1.00 & 0.68 & 0.22 & 0.25 & 0.03 & 0.87 & 0.6 & 0.74 & 0.44 \\
\hline FV3 & 0.9 & 3874 & 22.1 & 0.10 & 0.26 & 0.39 & 0.02 & 1.00 & 0.60 & 0.48 & 0.25 & 0.01 & 0.30 & 0.52 & 0.85 & 0.00 \\
\hline RD1 & 3.3 & 5833 & 57.0 & 0.37 & 0.34 & 1.07 & 0.01 & 1.00 & 0.92 & 0.60 & 1.00 & 0.02 & 0.85 & 0.53 & 0.90 & 0.78 \\
\hline OV1 & 3.8 & 12771 & 30.1 & 0.29 & 0.44 & 0.66 & 0.07 & 1.00 & 0.67 & 0.38 & 0.25 & 0.11 & 0.90 & 0.56 & 0.78 & 0.33 \\
\hline SD3 & 3.6 & 11444 & 31.3 & 0.30 & 0.43 & 0.70 & 0.06 & 0.96 & 0.80 & 0.49 & 0.50 & 0.02 & 0.90 & 0.71 & 0.84 & 1.00 \\
\hline SD4 & 7.4 & 14840 & 50.0 & 0.62 & 0.56 & 1.11 & 0.06 & 1.00 & 0.98 & 0.52 & 0.75 & 0.04 & 1.00 & 0.6 & 0.80 & 0.78 \\
\hline RD2 & 2.6 & 5571 & 47.0 & 0.29 & 0.33 & 0.88 & 0.01 & 0.89 & 0.87 & 0.45 & 0.00 & 0.00 & 0.85 & 0.69 & 0.92 & 1.00 \\
\hline SD5 & 6.5 & 21022 & 30.9 & 0.55 & 0.79 & 0.69 & 0.38 & 0.99 & 0.88 & 0.80 & 0.75 & 0.02 & 0.89 & 0.47 & 0.79 & 0.89 \\
\hline SD6 & 3.2 & 12865 & 24.6 & 0.27 & 0.49 & 0.55 & 0.11 & 0.99 & 0.88 & 0.45 & 0.75 & 0.08 & 0.93 & 0.43 & 0.81 & 0.78 \\
\hline OD3 & 3.4 & 19562 & 17.5 & 0.26 & 0.67 & 0.38 & 0.02 & 0.97 & 0.91 & 0.68 & 0.25 & 0.02 & 0.49 & 0.47 & 0.78 & 0.89 \\
\hline OD4 & 4.6 & 12123 & 38.0 & 0.35 & 0.42 & 0.84 & 0.02 & 1.00 & 0.98 & 0.50 & 0.50 & 0.04 & 1.00 & 0.55 & 0.95 & 0.78 \\
\hline OD5 & 3.5 & 13157 & 26.6 & 0.27 & 0.45 & 0.59 & 0.03 & 0.95 & 0.78 & 0.61 & 0.50 & 0.01 & 0.80 & 0.71 & 0.78 & 1.00 \\
\hline FV4 & 3.4 & 6831 & 50.0 & 0.40 & 0.46 & 0.88 & 0.20 & 0.98 & 0.80 & 0.67 & 0.00 & 0.20 & 0.10 & 0.44 & 0.99 & 0.33 \\
\hline FV5 & 3.2 & 7393 & 42.8 & 0.37 & 0.49 & 0.75 & 0.01 & 1.00 & 0.68 & 0.42 & 0.25 & 0.01 & 0.50 & 0.6 & 0.74 & 0.44 \\
\hline FV6 & 1.7 & 3552 & 47.0 & 0.20 & 0.24 & 0.82 & 0.01 & 0.98 & 0.80 & 0.49 & 0.25 & 0.01 & 0.43 & 0.48 & 0.76 & 0.44 \\
\hline RV1 & 3.6 & 7298 & 49.9 & 0.40 & 0.43 & 0.93 & 0.02 & 0.98 & 0.80 & 0.52 & 0.50 & 0.02 & 0.98 & 0.68 & 0.80 & 1.00 \\
\hline
\end{tabular}

${ }^{1}$ Y: Yield in $\mathrm{tha}^{-1}$; KN: Kernel number in grains per $\mathrm{m}^{2}$; TKW: Thousand kernel weight in $\mathrm{g} ;{ }^{2} \mathrm{RY}$ : Relative yield; RKN: Relative kernel number; RTKW: Relative thousand kernel weight; ${ }^{3}$ Ranging from 1 with no limitation to 0 with strong limitation.

The analysis of variance (ANOVA) was used to calculate least significant differences at the $P=0.05$ level.

\section{RESULTS AND DISCUSSION}

\subsection{Yield and yield components}

A wide range in yield and yield components was observed within the field network. Grain yield varied from 0.9 to $7.4 \mathrm{t} \cdot \mathrm{ha}^{-1}$, kernel number per $\mathrm{m}^{2}$ from 3552 to 21022 and thousand-kernel weight from 17.5 to $57 \mathrm{~g}$ (Tab. III).

Figure 1 shows the variability in kernel number per square meter and thousand-kernel weight for each genotype: Kernel numbers were well below the cultivar-specific reference values while thousand-kernel weights were below or close to the reference values.

For genotypes Florence Aurore and Renan, yield variations were associated with variations in kernel number. The coefficients of correlation between yield and kernel number were, respectively, 0.89 and 0.68 , while they were 0.45 and 0.09 for Sideral and Soissons, respectively. The correlation between grain yield and thousand-kernel weight was very low for all genotypes ( $\mathrm{r}^{2}$ between 0.01 and 0.34$)$. Consequently, the reduction in grain yield (RY) was positively correlated to $\mathrm{RKN}\left(\mathrm{r}^{2}=\right.$ $0.46)$ and slightly to RTKW $\left(r^{2}=0.26\right)$. No correlation was found between RKN and RTKW $\left(r^{2}=0.05\right)$, suggesting independent limiting factors during grain number formation and grain filling (Brancourt-Humel et al., 1999). 
(a)
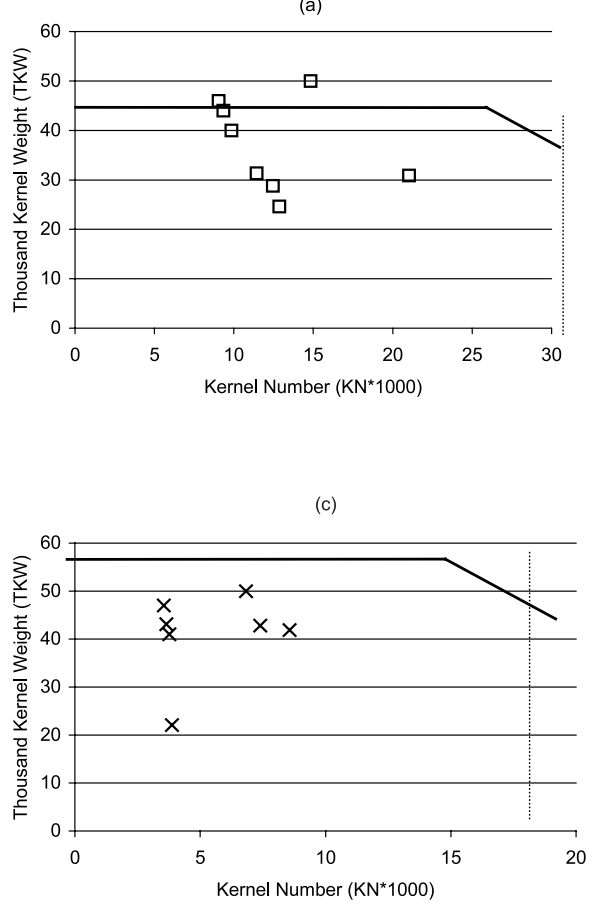

(b)
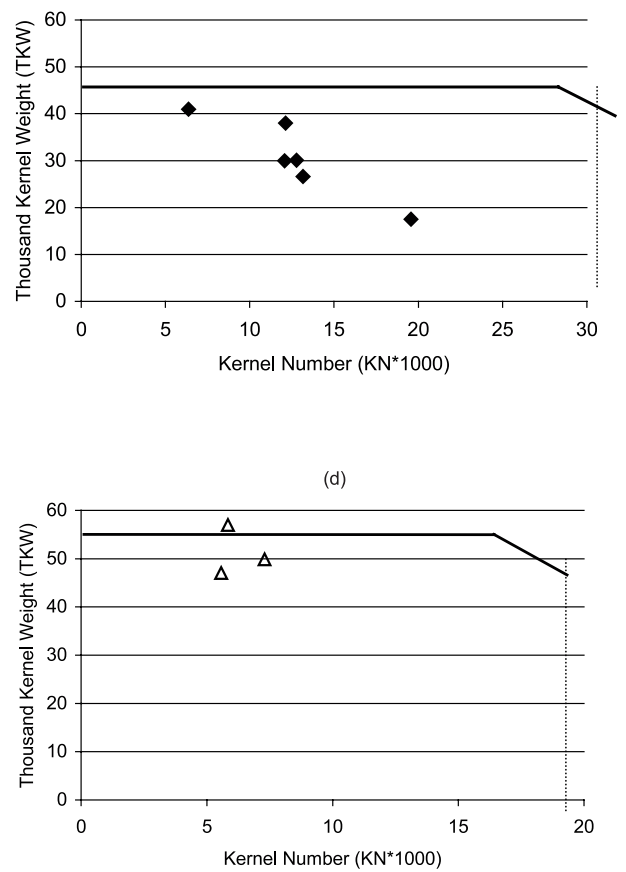

Figure 1. Relation between kernel number $(\times 1000)$ per $\mathrm{m}^{2}$ and thousand-kernel weight (in $\left.\mathrm{g}\right)$ compared with boundary curve reference values (See text for explanation). (a) Sidéral genotype. (b) Soissons genotype, (c) Florence Aurore genotype, (d) Renan genotype.

\subsection{Environmental status of the field network}

\subsubsection{Weather conditions}

The field network offered a wide range in weather conditions between years. Cumulative rainfall over the crop cycle ranged from 242 to $923 \mathrm{~mm}$ (Tab. I). According to the water balance index, most fields did not experience water deficits before flowering (HF ranged from 0.89 to 1.00 , Tab. III) while large deficits occurred after flowering, with the index ranging from 0.26 to 0.71 (Tab. III). Over the crop cycle, mean temperature ranged from $9.5^{\circ} \mathrm{C}$ to $14{ }^{\circ} \mathrm{C}$ among the fields (Tab. I). There were differences between regions: the Diois, surrounded by mountains, had a mean temperature of $9.7 \pm 0.2^{\circ} \mathrm{C}$ and the Val de Drôme of $11.2 \pm 1.2^{\circ} \mathrm{C}$. Finally, mean daily temperatures over $25^{\circ} \mathrm{C}$ were frequently observed after flowering in the Val de Drôme, but seldom in the Diois (Tab. III). Differences in weather conditions between the two areas were taken into account as the variable LOC in the multiple regression (see Sect. 3.3).

\subsubsection{Weed density}

Weed density varied widely from 1 to 423 plants per $\mathrm{m}^{2}$ with a mean of $56 \pm 52$ at flowering and a mean of $74 \pm 52$ at the soft-dough stage (Tab. III). Weed density and diversity increased as the crop cycle progressed (data not shown). At flowering, 51 species were identified. Among them, 7 species (Polygonum convolvulus, Polygonum aviculare, Chenopodium album, Artemisia vulgaris, Stellaria media, Veronica persica and Alopecurus agrestis) represented $57 \%$ of the total population. Furthermore, the frequencies of perennial weeds such as
Cirsium arvense (observed in 15 fields out of 24), and graminae as Lolium perenne and Avena fatua (observed in 12 fields out of 24) were high. In some fields, weeding operations significantly reduced the weed population (e.g. fields SD2, FD1, FV2, OV1 and RD1), while, on others, weed density remained very high throughout the crop cycle (e.g. fields SD1, SV2, FV3, RD2, SD6 and FV5).

\subsubsection{Soil compaction}

The majority of the fields showed soil compaction (Tab. III), reducing the arable layer volume from 20 to $40 \%$. Although the dominant internal state of clods was characterized by a lack of visible porosity, root depth exceeded $90 \mathrm{~cm}$ except in three cases (fields OD2, SD3 and FV6). The structure of the subsoil was rather favorable and not affected by topsoil compaction beyond a depth of $50 \mathrm{~cm}$.

\subsubsection{Foliar diseases}

The disease severity index varied from 1 to 0.3 (Tab. III), with a mean of $0.73 \pm 0.26$, at the soft-dough stage. Brown rust and Septoria nodorum were frequently observed, while mildew and yellow rust attacks were rare.

\subsubsection{Nitrogen nutrition}

Nutrient deficiencies were frequently observed. At flowering, the crop nitrogen nutrition index (NNIf) varied from 0.80 to 0.22 (Tab. III). A mean of $0.47 \pm 0.14$ indicated frequent and considerable $\mathrm{N}$ deficiencies. 
Table IV. Statistical analysis of reduction of Thousand Kernel Weight (RTKW) by the significant environment states based on the model RTKW = constant $+\mathrm{STH}+\mathrm{Hd}+\mathrm{SC}+$ Loc.

\begin{tabular}{|c|c|c|c|c|}
\hline & Degrees of freedom & Sum of squares & $\operatorname{Pr}>\mathrm{F}$ & Model quality \\
\hline \multicolumn{5}{|l|}{$\begin{array}{l}\text { (A) Analysis } \\
\text { of variance }\end{array}$} \\
\hline \multicolumn{5}{|l|}{ Source } \\
\hline Model & 4 & 0.352 & 0.02 & Adj $R^{2}=0.42$ \\
\hline Residual & 19 & 0.481 & & $\mathrm{RMSE}=0.16$ \\
\hline Total & 23 & 0.834 & & \\
\hline \multicolumn{5}{|c|}{ (B) Estimations of the effects of the factor: Constant $=-0.557$} \\
\hline Variables & & Estimated coefficient & $P$ value & \\
\hline Sum of temperature $(\mathrm{STH})^{1}$ & 1 & 1.310 & 0.007 & \\
\hline High temperature index $(\mathrm{Hd})^{1}$ & 1 & 0.433 & 0.04 & \\
\hline Soil compaction (SC) ${ }^{1}$ & 1 & 0.282 & 0.06 & \\
\hline Location $(\mathrm{LOC})^{2}$ & 1 & -0.317 & 0.02 & \\
\hline
\end{tabular}

${ }^{1}$ Index ranged from 0 to $1 ;{ }^{2}$ Location: If Diois $\mathrm{LOC}=1$; if Val de Drôme LOC $=0$.

Table V. Statistical analysis of reduction of kernel number $(\mathrm{RKN})$ by significant environment states based on the model $\mathrm{RKN}=\mathrm{constant}+1 /$ WF + NNIf.

\begin{tabular}{|c|c|c|c|c|}
\hline & Degrees of freedom & Sum of squares & $\operatorname{Pr}>\mathrm{F}$ & Model quality \\
\hline \multicolumn{5}{|l|}{ (A) Analysis of variance } \\
\hline \multicolumn{5}{|l|}{ Source } \\
\hline Model & 2 & 0.255 & 0.0001 & Adj $R^{2}=0.53$ \\
\hline Residual & 21 & 0.189 & & $\mathrm{RMSE}=0.09$ \\
\hline Total & 23 & 0.444 & & \\
\hline \multicolumn{5}{|c|}{ (B) Estimations of the effects of the factor: Constant $=0.112$} \\
\hline Variables & & Estimated coefficient & $\mathrm{P}$ value & \\
\hline Weed density (1/WF) & 1 & 0.200 & 0.049 & \\
\hline Nitrogen nutrition index (NNIf) & 1 & 0.609 & 0.000 & \\
\hline
\end{tabular}

WF Weed density at flowering in plants per $\mathrm{m}^{2}$, NNIf Nitrogen nutrition index at flowering (ranged from 0 to 1.2).

\subsection{Relationship between yield components and indicators of limiting factors}

\subsubsection{Analysis of relative kernel number (RKN) with respect to pre-flowering limiting factors}

Conditions during the period in which grain number is determined are reflected in the values of indicators of yield-limiting factors at flowering. These include weed population (1/WF), nitrogen nutrition index (NNIf), cumulative water deficit (HF), photothermal quotient (QF), location (LOC) and soil compaction (SC). In the parsimonious model, only $1 / \mathrm{WF}$ and NNIf were significant at $10 \%$ (Tab. IV). The percentage of yield variation explained by the regression model was adequate (Adj. $\mathrm{R}^{2}=0.53$ ) with a RMSE of 0.09. The NNIf had a strong and positive effect on relative kernel number, while weed density had a negative effect.

\subsubsection{Analysis of relative thousand-kernel weight (RTKW) with respect to yield-limiting factors}

The period of grain filling, and corresponding RTKW, was related to post-anthesis yield-limiting indicators, including weed population (WH) and disease severity (D) at the softdough stage, cumulative water deficit $(\mathrm{HH})$ from flowering to harvest, number of days with mean temperature over $25^{\circ} \mathrm{C}$ (Hd), temperature sum from flowering to harvest (STH), nitrogen nutrition at flowering (NNIf), location (LOC) and soil compaction (SC). In the parsimonious model, STH, Hd, SC and LOC were significant at $10 \%$ (Tab. V). The duration of the period of grain filling, reflected in the temperature sum, had a strong and positive effect on kernel weight. Soil compaction and high temperature had a negative influence on RTKW. Adjusted $\mathrm{R}^{2}$ for the model was 0.42 with a RMSE of 0.16 . 
Table VI. P values of the analysis of variance between significant limiting factors and cropping systems.

\begin{tabular}{lcccccccc}
\hline & CR & PC & SD & Ntot & Norg & Nap & S & loc \\
\hline NNIf & $0.005 * * *$ & $0.017 * *$ & 0.9141 & 0.5888 & 0.9632 & 0.1339 & 0.7040 & 0.1095 \\
$1 / \mathrm{WF}$ & 0.624 & 0.816 & 0.136 & 0.307 & 0.168 & 0.594 & 0.239 & 0.433 \\
$1 / \mathrm{WH}$ & 0.576 & $0.099 *$ & $0.092 *$ & 0.143 & 0.260 & 0.914 & $0.076 *$ & 0.393 \\
SC & 0.713 & 0.574 & 0.106 & 0.240 & 0.943 & $0.090 *$ & 0.444 & $0.009 * * *$ \\
\hline
\end{tabular}

$* P$ value $<0.10 ; * * P$ value $<0.05 ; * * * P$ value $<0.01$.

\subsection{Effects of crop management on limiting factors}

\subsubsection{Effects of cropping system on nitrogen nutrition}

Nitrogen status of winter wheat crops at flowering was significantly correlated to crop rotation and preceding crop (Tab. VI). Legumes, as preceding crop and within the crop rotation, improved nitrogen nutrition (NNIf $=0.51 \pm 0.12$ for a crop rotation with a high rate of legumes vs. $0.41 \pm 0.11$ for a crop rotation with a low rate of legumes). Moreover, there is a positive relationship between NNIf and Norg in 3 out of 4 cases (two areas, two crop rotations).

\subsubsection{Effects of cropping system on weed density}

Variations in weed density at the soft-dough stage were correlated to preceding crop, sowing date and soil type even though the effects were not significant at flowering (Tab. VI). Over the three years, sowing before November 1st led to higher weed density than later. Loamy and calcareous soil (soil 2) had significantly more weeds than sandy soils (soils 3 and 4). Frequent weeding operations (Tab. I) did not significantly limit weed density on stony soils (soils 1 and 2). Finally, forage legumes as preceding crop limited weed density during grain filling, especially that of springtime species.

\subsubsection{Effects of cropping system on soil compaction}

Soil compaction was weakly correlated to sowing date (Tab. VI). Over the three years, sowing before November 1st was associated with better soil structure. There was a difference between the two regions, Val de Drôme versus Diois, with a higher frequency of soil compaction in Val de Drôme, essentially associated with sowing dates (Tab. I).

\subsection{Significance}

The field network reflected the diverse crop management, weather and soil conditions faced by organic crop producers. It also demonstrated multiple limiting factors including weed competition, disease, soil compaction, nutrient deficiencies, water deficiencies and temperature stress.

\subsubsection{Variation in grain yield}

Yields varied considerably due to interactions among crop management systems, cropping history, soils and weather. For the 24 fields, the coefficient of variation for grain yield was $40 \%$ with an average of $3.5 \mathrm{t} \cdot \mathrm{ha}^{-1}$. These values are comparable with or greater than those reported in the literature on organic winter wheat (Bulson et al., 1996; Holle and Untiedt, 1999; Tamis and van den Brink, 1999; Olesen et al., 2002). Furthermore, organic wheat yield was consistently lower and more variable than reported for conventional agriculture (Meynard et al., 1981; Leterne et al., 1994).

\subsubsection{Environmental characteristics}

\subsubsection{Nitrogen nutrition}

Kernel set was strongly affected by $\mathrm{N}$ deficiency before flowering. This is consistent with results from Jeuffroy and Bouchard (1999), who demonstrated that severe and/or extended nitrogen deficiencies resulted in reduced kernel number. $\mathrm{N}$ deficiency could be partly correlated to insufficient soil N supply, less than $100 \mathrm{~kg} \mathrm{~N} \cdot \mathrm{ha}^{-1}$ on 6 fields out of 24 (Tab. I) or inadequate fertilization strategies. In the late $90 \mathrm{~s}$, nitrogen management was based on the assumption that organic fertilizer (e.g. feather meal, guano) should be applied early in the crop cycle to be available during stem elongation (Köpke, 1995). This resulted in early (before Feekes 4), single and low application rates (under $100 \mathrm{~kg} . \mathrm{N} \cdot \mathrm{ha}^{-1}$ ), also because of the high price of organic fertilizers (from 1.7 to $4.5 € \mathrm{~kg}^{-1} \mathrm{~N}$ ). However, David et al. (2004) have demonstrated the low crop N recovery of organic fertilizer applied before Feekes 4 . Furthermore, the mismatch between low crop demand and high $\mathrm{N}$ availability from organic fertilizers or liquid and fresh manures (e.g. pig and poultry manures) induces ammonia volatilization, thus leading to low fertilizer N recovery (Frost, 1994; SteinBachinger and Werner, 1997; Limaux et al., 1999; Pang and Letey, 2000; Olesen et al., 2002). Other limiting factors such as weeds (Angonin et al., 1996; McGloskey et al., 1998), water deficit (Sebillotte et al., 1978) and/or soil compaction (Wibawa, 1992) have limited crop N nutrition. Finally, the substantial effect of crop rotation and preceding crop on $\mathrm{N}$ plant status concurs with earlier statements (Köpke, 1995) emphasizing the importance of long-term $\mathrm{N}$ management strategies using nitrogen-fixing legumes.

\subsubsection{Weed competition}

The organic wheat fields monitored in this study were characterized by a diversity of weed species, as has been found previously in other studies (Hyvonen et al., 2003; Moreby et al., 1994). Weed density at flowering was found to have a significant negative effect on kernel number. When weed density was high, even frequent weeding (Tab. I) did not prevent serious reductions in yield (Rasmussen, 1993). The effectiveness of 
mechanical weed control is affected by soil type and conditions, weed species composition, and the relative growth stage of the crop and weeds (Rasmussen and Ascard, 1995). In this study, a later sowing date resulted in lower weed densities. In conventional practice, autumn cereals are drilled early to achieve high yields. However, later sowings allowed for additional cultivation to prepare a seedbed that best serves weed control purposes (Bond and Grundy, 2001; Leake, 1996; Cousens, 1985). Our results emphasize the difficulty of controlling weeds by springtime harrowing in stony and heavy soils. Especially, the early emergence of dominant species (representing more than $80 \%$ of the total population), such as Veronica hederifolia on fields SD1, SD2 and RD2 and Alopecurus myosuroides on field F6, made these difficult to control by springtime harrowing, and this partly explains the final result.

\subsubsection{Soil compaction}

Soil compaction was frequent in the organic field network, mainly caused by adverse sowing conditions. Slow-draining fields where farmers worked under conditions that were too wet, involving several soil cultivations (minimum of 2 passes) after ploughing, resulted in severe compaction in the ploughed layer. Even when porosity and aggregate stability were reduced by topsoil compaction, rooting was significant, to a maximum depth of 90 to $120 \mathrm{~cm}$ in most fields. Consequently, root development probably compensated for topsoil compaction during the vegetative phase, with $\mathrm{N}$ uptake from deeper soil layers (Oussible et al., 1993). Nonetheless, soil compaction may lead to reduced root size, delayed root penetration and reduced water and nutrient uptake (Tardieu, 1984; Lipiec and Hatamo, 2003). The combination of soil compaction and water deficit may negatively affect grain filling (Busscher et al., 2001).

Liebig and Doran (1999) concluded that the capacity of organic farms to improve soil quality derives from diverse crop sequences, inclusion of forage crops, application of organic amendments, and less frequent tillage. In this field network, crop rotation was characterized by a low frequency of forage legumes (15\%) and a high proportion of wheat (40\%). Moreover, not all farms applied organic amendments before ploughing, while fresh chicken manure was applied at springtime on 10 fields out of 24 .

\subsubsection{Pest and disease}

In our network, the use of disease-resistant genotypes allowed for the control of Septoria nodorum. Our results confirmed that losses due to foliar disease can be low in organic wheat (Van Bruggen, 1995; McKinlay, 1999).

\subsubsection{Weather variables}

Weather conditions before wheat anthesis influence the number and size of ears and determine the potential number of grains (Parameswaran et al., 1984; Fischer, 1985; DemotesMainard and Jeuffroy, 2001). The field network was characterized by intense water deficit after flowering stages. However, this indicator did not statistically explain kernel number because of its limited differentiation among fields (Tab. III).

A higher temperature sum over the grain-filling period was associated with higher kernel weight in our experiment. Higher temperature and radiation in Val de Drôme led to higher kernel weight than in Diois. Finally, temperatures exceeding $25^{\circ} \mathrm{C}$ negatively affected grain filling, in agreement with Sofield et al. (1977).

Acknowledgments: This research was funded by the European Commission (Contract AIR3 CT0852). We would like to give special thanks to Y. Gautronneau (ISARA Lyon), A. Bonnardel, B. Chareyron and O. Durant (Chambre d'agriculture de la Drôme), and also to the enthusiastic organic farmers (A. Bonnard, M. Breyton, J.M. Chancel, P. Gautronneau, P. Géry, A. Guichard, V. Lefort, H. Marce, D. Roux, J. Segond and J. Serratrice).

\section{REFERENCES}

Angonin C., Caussanel J.P., Meynard J.M. (1996) Competition between winter wheat and Veronica hederifolia: influence of weed density and the amount and timing of nitrogen application, Weed Res. 36, $175-187$.

Aubry C., Latiri-Souki K., Doré T., Griner C. (1994) Diagnostic des facteurs limitants du rendement du blé dur en parcelles d'agriculteurs dans une petite région semi-aride en Tunisie, Agronomie 14, 213 227.

Barberi P. (2002) Weed management in organic agriculture. Are we addressing the right issues? Weed Res. 42, 177-193.

Berry P., Sylvester-Bradley R., Philipps L., Hatch D.J., Cuttle S.P., Rayns F.W., Gosling P. (2002) Is the productivity of organic farms restricted by the supply of avalaible nitrogen? Soil Use Manage. 18, $248-255$.

Boiffin J., Caneill J., Meynard J.M., Sebillotte M. (1981) Élaboration du rendement et fertilisation azotée du blé en Champagne crayeuse. I. Protocole et méthode d'étude d'un problème technique régional, Agronomie 1, 549-558.

Bond W., Grundy A.C. (2001) Non-chemical weed managment in organic farming systems, Weed Res. 41, 383-405.

Brancourt-Hulmel M., Lecomte C., Meynard J.M. (1999) A diagnosis of yield-limiting factors on probe genotypes for characterizing environments in winter wheat trials, Crop Sci. 39, 1798-1808.

Brisson N., Seguin B., Bertuzzi P. (1992) Agrometeorological soil water balance for crop simulation models, Agr. Forest Meteorol. 59, 267-287

Bulson H.A.J., Welsh J.P., Stope C.E., Woodward L. (1996) Agronomic viability and potential economic performance of three organic fouryear rotations without livestock, 1988-1995, Asp. Appl. Biol. 47, 277-286.

Busscher W.J., Frederick J.R., Bauer P.J. (2001) Effect of penetration resistance and timing of rain on grain yield of narrow-row corn in a coastal plain loamy sand, Soil Till. Res. 63, 15-24.

Cousens R. (1985) A simple model relating yield loss to weed density, Ann. Appl. Biol. 107, 239-252.

David C., Gautronneau Y. (2002) Soil fertility in organic arable systems, in: Proc. of the International Federation of Organic Agriculture Movements, Vancouver, Canada, p. 33.

David C., Jeuffroy M.H., Recous S., Dorsainvil F. (2004) Adaptation and assessment of the Azodyn model for managing the nitrogen fertilization of organic wheat, Eur. J. Agron. 21, 249-266.

Demotes-Mainard S., Jeuffroy M.H. (2001) Incorporating radiation and nitrogen nutrition into a model of kernel number in wheat, Crop Sci. 41, 415-423.

Deria A.M., Bell R.W., O’Hara G.W. (2003) Organic wheat production and soil nutrient status in a Mediterranean weather zone, J. Sustain. Agr. 21, 21-47.

Doré T., Sébillotte M., Meynard J.M. (1997) A diagnostic method for assessing regional variations in crop yields, Agr. Syst. 54, 169-188. 
Dunbabin V.M., Diggle A.J., Rengel Z., Van Hugten R. (2002) Modelling the interactions between water and nutrient uptake and root growth, Plant Soil 239, 19-38.

Edwards-Jones G., Howells O. (2001) The origin and hazard of inputs to crop protection in organic farming systems: are they sustainable? Agr. Syst. 67, 31-47.

European Commission (2001) Organic farming in the EU: facts and figures, $18 \mathrm{p}$.

FAO (1998) Top-soil characterization for sustainable land management, FAO LW division, Rome.

Fischer R.A. (1985) Number of kernels in wheat crops and the influence of soliar radiation and temperature, J. Agr. Sci. Camb. 105, 447461.

Fleury A., Limaux F. (1987) Comment la comparaison globale de nombreux essais a pu conduire à des références régionales pour le blé en Lorraine, B.T.I. 417, 95-110.

Frost J.P. (1994) Effect of spreading method, application rate and dilution on ammonia volatilization from cattle slurry, Grass Forage Sci. 49, 391-400.

Gate P. (1995) Ecophysiologie du blé ; de la plante à la culture, Lavoisier, Paris.

Girard M.L. (1997) Modélisation de l'accumulation de biomasse et d'azote dans les grains de blé tendre d'hiver ; simulation de leur teneur en protéines à la récolte. Thèse doctorat INA Paris-Grignon, Paris, France.

Halberg N., Kristensen I.S. (1997) Expected crop yield loss when converting to organic dairy farming in Denmark, Biol. Agric. Hortic. $14,25-41$.

Hamilton L.C. (2002) Statistics with STATA, Duxbury press, USA

Holle R., Untiedt H. (1999) Crop rotations on organic farms in Northern Germany and development of the wide row system, in: Olesen J.E. Eltun R., Gooding M.J., Jensen E.S., Köpke U. (Eds.), Designing and testing crop rotations for organic farming, DARCOF Copenhagen, Denmark, pp. 159-162.

Hyvonen T., Ketoja E., Salonen J., Jalli H., Tiainen J. (2003) Weed species diversity and community composition in organic and conventional cropping of spring cereals, Agr. Ecosyst. Environ. 97, 131149.

Jeuffroy M.H., Bouchard C. (1999) Intensity and Duration of Nitrogen Deficiency on Wheat Grain Number, Crop Sci. 39, 1385-1393.

Justes E., Mary B., Meynard J.M., Machet J.M., Thelier-Huche L. (1994) Determination of a critical nitrogen dilution curve for winter wheat crops, Ann. Bot. 74, 397-407.

Keatinge R., Cormack W., Padel S., Wolfe M. (2000) A review of current European research on organic farming, Reports of project OF0171, MAFF, London, UK.

Kho R.M. (2000) On crop production and the balance of available resources, Agr. Ecosyst. Environ. 80, 71-85.

Köpke U. (1995) Nutrient management in organic systems: the case of nitrogen, Biol. Agric. Hortic. 11, 15-29.

Lammerts van Bueren E.T., Struik P.C., Jacobsen E. (2002) Ecological concepts in organic farming and their consequences for an organic crop ideotype, Neth. J. Agr. Sci. 50, 1-26.

Landau S., Mitchell R.A.C., Barnett V., Colls J.J., Craignon J., Payne R.W. (2000) A parsimonious, multiple-regression model of wheat yield response to environment, Agr. Forest Meterol. 101, 151-166.

Leake A.R. (1996) The effect of cropping sequences and rotational management: An economic comparison of conventional, integrated and organic systems, Asp. Appl. Biol. 47, 185-194.

Le Bail M., Meynard J.M. (2003) Yield and protein concentration of spring malting barley: The effects of cropping systems in the Paris Basin (France), Agronomie 23, 23-27.
Lemaire G., Gastal F. (1997) N uptake and distribution in plant canopies. Diagnosis of the nitrogen status in crops, in: Lemaire G. (Ed.), Springer, Berlin, pp. 3-43.

Leterme P., Manichon H., Roger-Estrade J. (1994) Analyse intégrée des rendements du blé tendre et de leurs causes de variation dans un réseau de parcelles d'agriculteurs du Thymerais, Agronomie 14, 341-361.

Liebig M.A., Doran J.W. (1999) Impact of organic production practices on soil quality indicators, J. Environ. Qual. 28, 1601-1609.

Limaux F., Recous S., Meynard J.M., Guckert A. (1999) Relationship between rate of crop growth at date of fertiliser $\mathrm{N}$ application and fate of fertiliser N applied to winter wheat, Plant Soil 214, 49-59.

Lipiec J., Hatamo R. (2003) Quantification of compaction effects on soil physical properties and crop growth, Geoderma 116, 107-136.

Loyce C., Rellier J.P., Meynard J.M. (2002) Management planning for winter wheat with multiple objectives (2): ethanol-wheat production, Agr. Syst. 72, 33-57.

Machet J.M., Dubrulle P., Louis P. (1991) AZOBIL: a computer program for fertiliser $\mathrm{N}$ recommendations based on a predictive balance sheet method, Proc. I ESA Congress Scientific Conference, Paris, France, pp. 21-22.

Mäder P., Fliessbach A., Dubois D., Gunst L., Fried U., Niggli U. (2002) Soil fertility and biodiversity in organic farming, Science 296 , 1694-1697.

McGloskey M.C., Firbank L.G., Watkinson A.R., Webb D.J. (1998) Interactions between weeds of winter wheat under different fertilizer, cultivation and weed management treatments, Weed Res. 38, $11-24$.

McKinlay R.G. (1999) Review of crop protection, in: ENOF White Book Organic farming research in the EU, Towards 21 st century, Barcelona, Spain.

Meynard J.M., Boiffin J., Caneill J., Sebillotte M. (1981) Élaboration du rendement et fertilisation azotée du blé en Champagne crayeuse. II. Types de réponse à la fumure azotée et application de la méthode du bilan prévisionnel, Agronomie 1, 795-806.

Meynard J.M. (1985) Construction d'itinéraires techniques pour la conduite de blé d'hiver, Thèse doctorat INA-Paris-Grignon, Paris, France.

Meynard J.M., David G. (1992) Diagnostic sur l'élaboration du rendement des cultures, Cah. Agr. 1, 9-19.

Meynard J.M., Cerf M., Guichard L., Jeuffroy M.H., Makowski D. (2002) Which decision support tools for the environment management of nitrogen? Agronomie 22, 817-829.

Moreby S.J., Aebischer N.E., Southway S.E., Sotherton N.W. (1994) A comparison of the flora and arthropod fauna of organically and conventionally grown winter wheat in Southern England, Ann. Appl. Biol. 125, 13-27.

Observatoire National de l'Agriculture Biologique (2003) Les principaux résultats de l'année 2003, Paris, France.

Offermann F., Nieberg H. (2000) Economic performance of organic farms in Europe in Organic farming in Europe: economics and policy, University of Hohenheim (Eds.), Germany.

Olesen J.E., Rasmussen I.A., Askegaard M., Kristensen K. (2002) Wholerotation, dry matter and nitrogen yields from the first course of an organic farming crop rotation experiment, J. Agr. Sci. 139, 361370.

Oussible M., Allmaras R.R., Wych R.D. Crookston R.K. (1993), Subsurface compaction effects on tillering and nitrogen accumulation in wheat, Agron. J. 85, 619-625.

Pang X.P., Letey J. (2000) Organic farming: challenge of timing nitrogen availability to crop nitrogen requirements, Soil Sci. Am. J. 64, 247 253. 
Parameswaran K.V.M., Graham R.D., Aspinall D. (1984) Studies on the nitrogen and water relations of wheat. II. Effects of varying nitrogen and water supply on growth and grain yield, Irrig. Sci. 5, 105-121.

Rasmussen J. (1993) Can high densities of competitive weeds be controlled efficiently by harrowing or hoeing in agricultural crops? in: 4th International Conference IFOAM, Non-chemical weed control, Dijon, France, pp. 85-89.

Rasmussen J., Ascard J. (1995) Weed control in organic farming systems, in: Glen D.M., Greaves M.P., Anderson H.M. (Eds.), Proceedings 13th Long Ashton International Symposium, Ecology and Integrated Farming SystemsChichester, UK, pp. 49-67.

Roger-Estrade J., Richard G., Caneill J., Boizard H., Coquet Y., Defossez P., Manichon H. (2004) Morphological charaterisation of soil structure in tiled fields: from a diagnosis method to the modeling of structural changes over time, Soil Till. Res. 79, 33-49.

Sebillotte M. (1980) An analysis of yield elaboration in wheat, in: Wheat technical monograph, CIBA-GEIGY, Basel, Switzerland, pp. 2532.

Sebillotte M., Boiffin J., Caneill J., Meynard J.M. (1978) Sécheresse et fertilization azotée du blé d'hiver, Bull. AFES 3, 197-213.

Shepherd M.A., Harrison R., Webb J. (2002) Managing soil organic matter-implications for soil structure on organic farms, Soil Use Manage. 18, 284-292.

Sofield I., Evans L.T., Cook M.G., Wardlaw I.F. (1977) Factors influencing the rate and duration of grain filling in wheat, Aust. J. Plant Physiol. 4, 785-797.

Stein-Bachinger K., Werner W. (1997) Effect of manure on crop yield and quality in an organic agricultural system, Biol. Agric. Hortic. $14,221-235$

Stewart D.W., Dwyer L.M. (1987) Analysis of phonological observations on barley (Hordeum vulgare) using the feekes scale, Agr. Forest Meteorol. 39, 37-48.
Tamm L. (2000) The future challenge and prospects in organic crop protection, Proc. International IFOAM scientific conference, Basel, Switzerland, pp. 106-109.

Tamis W.L.M., van den Brink W.J. (1999) Conventional, integrated and organic winter wheat production in The Netherlands in the period 1993-1997, Agr. Ecosyst. Environ. 76, 47-59.

Tardieu F. (1984) Étude au champ de l'enracinement du maïs, Influence de l'état structural sur la répartition des racines, Thèse doctorat INA Paris-Grignon, Paris, France.

Taylor B.R., Watson C.A., Stockdale E.A., McKinlay R.G., Younie D., Cranstoun D.A.S. (2001) Current practices and future prospects for organic cereal production: survey and literature review, HGCA (Ed.), London, UK, No. 45, 90 p.

Van Bruggen A.H.C. (1995) Plant disease severity in high-input compared to reduced-input and organic farming systems, Plant Dis. 79, 976-984.

Von Fragstein P. (1996) Organic arable farming - a contradiction? Proc. IV ESA Congress Scientific Conference, Veldhoven, Netherlands, pp. $438-439$.

Wallach D., Goffinet B. (1989) Mean squared error of prediction as a criterion for evaluating and comparing system models, Ecol. Model. 44, 299-306.

Warrington I.J., Dunstone R.L., Green L.M. (1977) Temperature effects at three development stages on the yield of the wheat ear, Aust. J. Biol. Sci. 23, 765-774.

Wibawa G. (1992) Approche par enquête et expérimentation de l'effet structural du sol sur la nutrition azotée et élaboration du rendement de l'orge de brasserie, Thèse doctorat INA Paris-Grignon, Paris, France. 